IFAS Extension

\title{
The mexican lac scale Tachardiella mexicana (Comstock) (Hemiptera: Kerriidae) ${ }^{1}$
}

\author{
lan Stocks ${ }^{2}$
}

\section{Introduction}

The Mexican lac scale, Tachardiella mexicana (Comstock) (Hemiptera: Kerriidae), is native to Mexico and Texas. This species was first discovered in Florida in 1985 at a theme park in Lake Buena Vista and a second population was discovered in 1987 at a nursery in Redlon (Seminole County) that is no longer in business. In 2006, a population was discovered in Fort Myers (Lee County), and a resampling of the area in 2010 revealed that the populations were established on the host trees. Before June 2010, all host records, including both previously published host records and unpublished host records maintained by the Division of Plant Industry (DPI), were from fabaceous plants such as Acacia spp., Pitheleocelobium flexicaule, Ebenopsis ebano and Lysiloma spp. However, in June 2010, a second population at Lake Buena Vista was discovered feeding on wax myrtle, Myrica cerifera (Myricaceae).

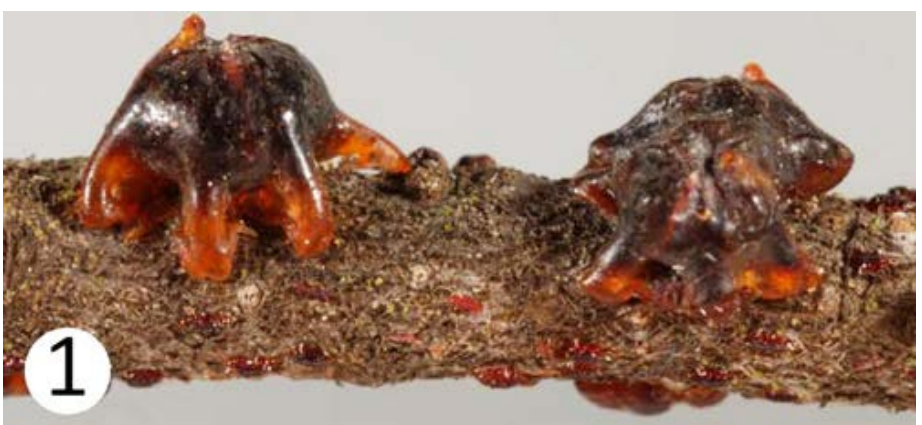

Figure 1. Adult female tests of Tachardiella mexicana on wax myrtle. Credits: Lyle Buss, University of Florida, Entomology and Nematology Department.

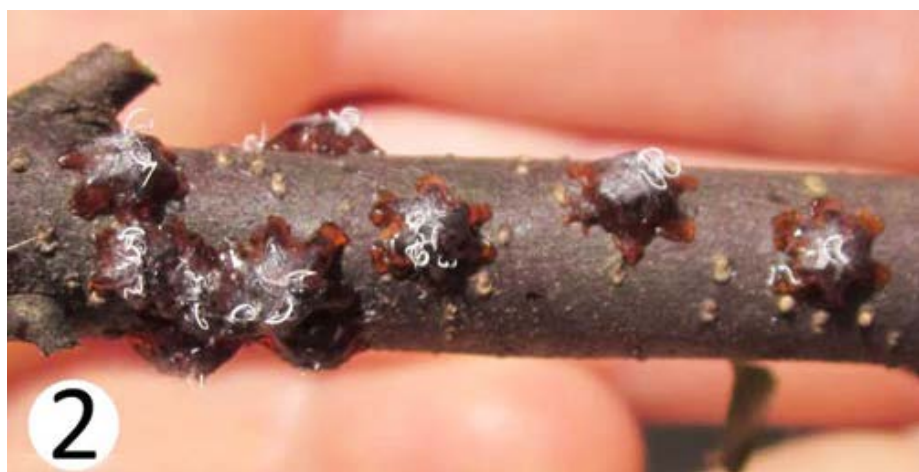

Figure 2. Adult female tests of Tachardiella mexicana on wax myrtle. Credits: Susan Halbert, Florida Department of Agriculture and Consumer Services, Division of Plant Industry.

\section{Distribution}

Central to southern Texas. Arizona. Florida (Lee County, Orange County and Seminole County). Mexico, bordering Texas.

\section{Description}

Adult female scales produce a high-domed 'test' or shell with four to six lobe-like projections that anchor the test to the plant surface (Figures 1, 2). The test is hard and glossy with a reddish-orange tint around the edges, and darker toward the center. In some specimens, white string-like wax fiber extrusions project from the dorsum of the test, but these may break off. In heavy infestations, the tests of multiple females will develop into a single, aggregated mass such that the distinctive appearance of the individual tests is lost (Figure 3). The test darkens as the scale matures.

1. This document is EENY 552, one of a series of the Entomology and Nematology Department, Florida Cooperative Extension Service, Institute of Food and Agricultural Sciences, University of Florida. Original publication date April 2013. Visit the EDIS website at http://edis.ifas.ufledu.

2. Ian Stocks, taxonomic entomologist, Florida Department of Agriculture and Consumer Services, Division of Plant Industry, and affiliate faculty, Entomology and Nematology Department, Institute of Food and Agricultural Sciences, University of Florida, Gainesville, FL 32611.

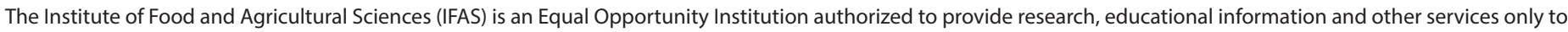

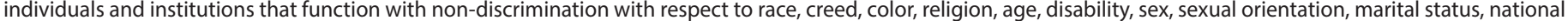
origin, political opinions or affiliations. U.S. Department of Agriculture, Cooperative Extension Service, University of Florida, IFAS, Florida A\&M University Cooperative Extension Program, and Boards of County Commissioners Cooperating. Nick T. Place, Dean 
The female scale, which is a deep red color, lives inside the test and requires a special procedure to remove without damage. Proper identification requires that specimens be slide-mounted.

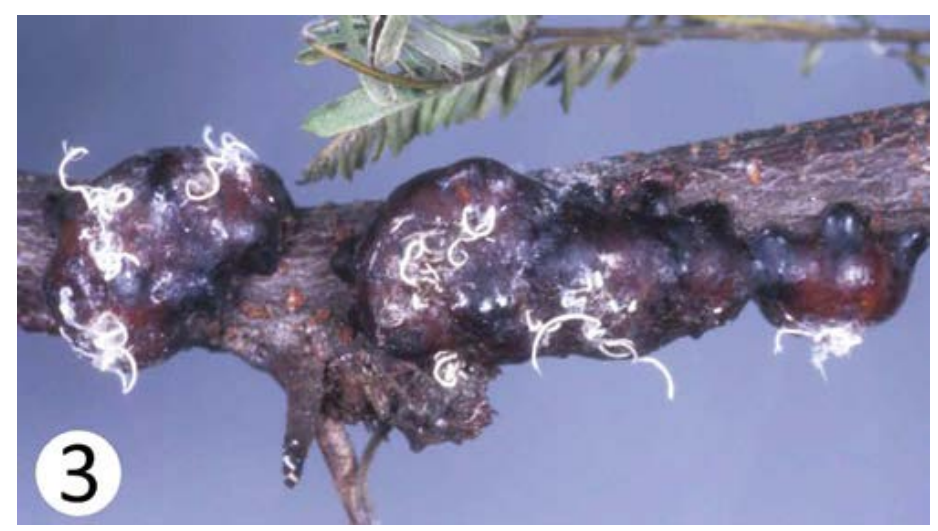

Figure 3. Adult female tests of Tachardiella mexicana.

Credits: University of Florida, Entomology and Nematology

Department.

The University of Florida, IFAS Lee County Extension Office, recently published an online factsheet with illustrations on the Mexican lac scale population in Lee County that is infesting wild tamarind (Lysiloma latisiliqua) (Brown 2011). This is the second of two lac scales known in Florida. In 1999, the lobate lac scale, Paratachardina pseudolobata, was discovered in Broward County, and is now widely distributed throughout southern Florida on many hosts. Lobate lac scale is easily distinguished from the Mexican lac scale by the former's distinctive lobed, or bow tie-shaped test (Figure 4). Wax myrtle is also a common host of lobate lac scale.

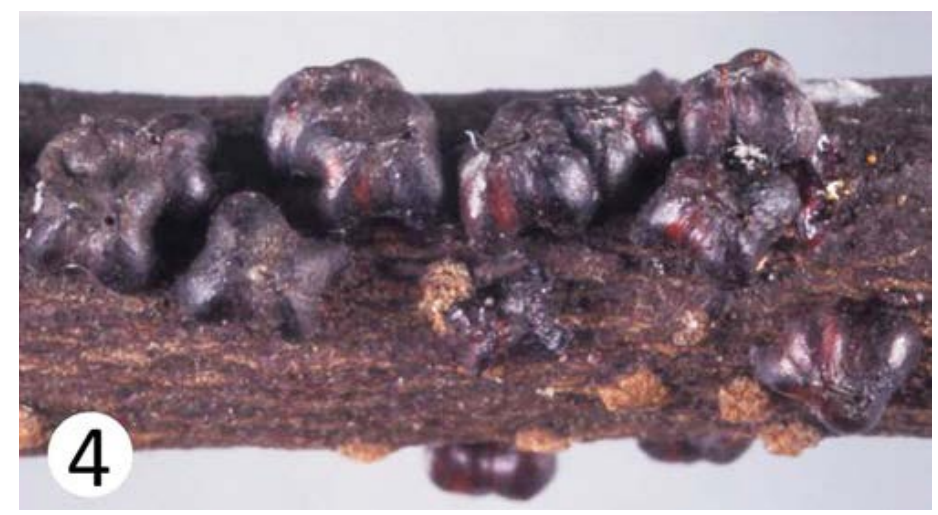

Figure 4. Adult female tests of Paratachardina pseudolobata. Credits: Lyle Buss, University of Florida, Entomology and Nematology Department.

\section{Biology}

There are no published observations on this species. In Florida, very high densities were observed on the woody parts of the wax myrtle plant. The infested wax myrtle showed significant dieback in large shrubs, and the most heavily infested small shrubs were dead. All parts of the infested wax myrtles, surrounding plants and ground were covered with sooty mold.

\section{Hosts}

Acacia cornigera, Acacia pinetorum, Ebenopsis ebano, Lysiloma sabicu, Lysiloma latisiliquum, Mimosa sp. (Fabaceae); Myrica cerifera (Myricaceae).

\section{Economic Importance}

There are no published reports of economic losses caused by this species. Gillian Watson (personal communication, CDFA) reports that even though an untreated infestation can kill a plant, it has not had an economic effect on succulent production in California.

\section{Natural Enemies}

The online scale database ScaleNet lists no natural enemy, but several parasitoids are recorded in the Universal Chalcidoidea Database (Noyes 2012) for the related species Tachardiella larreae (Comstock), also native to the southwestern United Sates (Texas, Arizona) and Mexico.

\section{Aphelinidae: Marietta albocephala Hayat}

Encyrtidae: Tachardobius nigricans Timberlake, Tachardobius vladimiri Triapitsyn. None of the parasitoids are currently known from Florida.

\section{Selected References}

Brown SH. 2011. Tachardiella mexicana on wild tamarind. University of Florida, IFAS Lee County Extension Office. (10 September 2012.)

Chamberlin JC. 1923. A systematic monograph of the Tachardiinae or Lac Insects (Coccidae). Bulletin of Entomological Research 14: 147-212.

Ferris G. 1955. Atlas of the scale insects of North America, v. 7, the families Aclerdidae, Asterolecaniidae, Conchaspididae, Dactylopiidae and Lacciferidae. iii. Stanford University Press, Palo Alto, California. 233 p. 
Howard FW, Pemberton R, Hamon A, Hodges GS, Steinberg B, Mannion CM, McLean D, Wofford J. 2004. Lobate Lac Scale, Paratachardina lobata lobata (Chamberlin) (Hemiptera: Sternorrhyncha: Coccoidea: Kerriidae). University of Florida, IFAS, EDIS. (10 September 2012.)

Kondo T, Gullan PJ. 2011. Taxonomic review of the genus Tachardiella Cockerell (Hemiptera: Kerriidae), with a key to species of lac insects recorded from the New World. Neotropical Entomology 40: 345-367.

Noyes JS. 2012. Universal Chalcidoidea Database. World Wide Web electronic publication. (10 September 2012.)

Triapitsyn S. 2008. A review of Tachardobius (Hymenoptera: Encyrtidae), with description of a new species from California, USA, a parasitoid of Tachardiella spp. (Hemiptera: Kerriidae). Zootaxa 1716: 44-52. 